\title{
Penggunaan Bahasa Indonesia Pada Artikel Dalam Laman (Website) Kantor Wilayah Kementerian Agama Kalimantan Barat Periode Oktober 2017- Januari 2018
}

\author{
Abid Fatoni ${ }^{1}$, Eti Sunarsih ${ }^{2}$, Lili Yanti ${ }^{3}$ \\ STKIP Singkawang, Singkawang, Indonesia \\ abidfatoni95@gmail.com ${ }^{1}$, etisunarsih89@gmail.com ${ }^{2}$, liliyantiana18@gmail.com³
}

\begin{tabular}{ll}
\hline \hline Keywords : & ABSTRACT \\
Artikel dalam Laman, Ejaan, & Penelitian ini bertujuan untuk mendeskripsikan : (1) \\
Kalimat, Diksi & penggunaan ejaan pada artikel dalam website Kantor Wilayah \\
& Kementerian Agama Kal-Bar, (2) penggunaan kalimat pada \\
artikel dalam website Kantor Wilayah Kementerian Agama & Kal-Bar, (3) penggunaan diksi pada artikel dalam website \\
& Kantor Wilayah Kementerian Agama Kal-Bar, (4) \\
& implementasi pembelajaran di sekolah tentang penggunaan \\
& ejaan, kalimat dan diksi pada artikel. Metode yang digunakan \\
dalam penelitian ini adalah metode deskriptif. Bentuk \\
penelitian ini adalah kualitatif. Sumber data yang digunakan \\
dalam penelitian ini adalah website Kantor Wilayah \\
Kementerian Agama Kalimantan Barat dengan situs http:// \\
kalbar.kemenag.go.id/id. Berdasarkan rumusan masalah yang \\
digunakan, penggunaan bahasa Indonesia dibagi menjadi tiga \\
yaitu ejaan, kalimat dan diksi. Terdapat 161 data kesalahan \\
penggunaan ejaan, 145 data kesalahan penggunaan kalimat, \\
dan 133 kesalahan penggunaan diksi. Hasil dari penelitian ini \\
dapat diimplementasikan pada kelas XII semester 2 dengan \\
Kompetensi Dasar 4.10 menyusun opini dalam bentuk artikel \\
dengan kegiatan pembelajaran menulis opini dalam bentuk \\
artikel dengan memperhatikan unsur-unsur artikel. \\
\hline \hline
\end{tabular}

\section{PENDAHULUAN}

Bahasa Indonesia merupakan bahasa resmi negara Indonesia. Oleh sebab itu setiap tuturan atau tulisan yang mencangkup bidang resmi harus menggunakan bahasa Indonesia yang baik dan benar. Penggunaan bahasa Indonesia yang baik dan benar dapat dilihat dari segi ejaan, diksi, kalimat efektif, dan paragraf dalam suatu tulisan. Terampilnya seseorang dalam berbahasa dapat dilihat pada kemampuan dalam menutur atau menulis ide kepada orang lain. Komunikasi yang sudah baik bisa terlihat dari pemahaman lawan tutur, apabila lawan tutur mengerti atau memahami apa yang diinformasikan penutur, itu berarti komunikasi yang terjadi sudah baik. Apabila lawan tutur tidak memahami apa yang disampaikan penutur, berarti telah terjadi sebuah komunikasi yang tidak baik yang bisa disebabkan oleh penutur. Untuk menyikapi hal tersebut, penutur harus meningkatkan kemampuan dan keterampilan penggunaan bahasa Indonesia melalui pembinaan yang konkrit dalam bidang bahas guna meningkatkan penggunaan bahasa yang baik dan benar agar tidak terjadi kesalah pahaman antara penutur dan lawan tutur. 
Artikel merupakan sebuah karya ilmiah menuntut kecermatan dalam penalaran bahasa karena sebuah karya tulis ilmiah yang berbentuk artikel ini harus memenuhi ragam bahasa standar yang formal dan bukan bahasa pergaulan. Suroso dalam Zubeir (2008: 1) menyatakan "artikel adalah jenis tulisan atau karangan yang berisi gagasan, ulasan atau kritikan terhadap suatu persoalan yang ada dan berkembang di tengah masyarakat dan ditulis dengan bahasa ilmiah popular". Selain itu, bahasa yang digunakan dalam artikel memiliki fungsi yang sangat penting. Bahasa di dalam artikel merupakan media pengungkapan gagasan penulis. Sehingga bahasa dalam artikel dituntut mampu mengungkapkan gagasan keilmuan secara tepat sehingga gagasan penulis dapat ditangkap pembaca secara tepat. Kesalahan penggunaan bahasa dalam artikel menyebabkan gagasan yang disampaikan penulis tidak dapat diterima pembaca dan bisa menyebabkan pemahaman pembaca bertolak belakang dengan gagasan penulis.

Penggunaan bahasa dalam penulisan artikel harus menggunakan bahasa Indonesia yang baik dan benar atau sesuai dengan Pedoan Umum Ejaan Bahasa Indonesia (PUEBI). Penulis sangat sering menemukan kesalahan-kesalahan tulisan yang terdapat di dalam artikel. Penulisan dalam sebuah artikel seharusnya lebih diperhatikan dan menggunakan kalimat yang lebih tepat, karena secara tidak langsung para pembaca akan belajar cara berbahasa Indonesia yang baik dan benar dari tulisan artikel tersebut. Khususnya untuk artikel-artikel yang dipublikasikan melalui situs-situs resmi milik pemerintah harus menggunakan bahasa Indonesia yang baik dan benar. Penggunaan bahasa dalam ruang lingkup pemerintahan harus menggunakan bahasa Indonesia yang baku dan akan menjadi contoh penggunaan bahasa Indonesia yang baik dan benar bagi masyarakat umum.

Kata laman atau website mungkin sudah tidak asing lagi di telinga kita. Laman merupakan sebuah jejaring sosial yang berisi halaman-halaman informasi dan bisa diakses melalui internet kapan saja dan di mana saja yang bisa mempermudah kita untuk saling berbagi informasi maupun pengalaman. Menurut Yuhefizar (dalam Prayitno dan Safitri, 2015: 2) "laman adalah keseluruhan halaman-halaman web yang terdapat dari sebuah domain yang mengandung informasi". Laman kantor wilayah kementerian agama merupakan laman yang bersifat resmi dan menggunakan ragam bahasa resmi juga. Hal tersebut yang membuat penulis tertarik untuk menjadikan laman kantor wilayah kementerian agama sebagai sumber dalam penelitian ini. Alasan penulis yang membuat penelitian kesalahan penggunaan bahasa pada artikel dalam laman kementerian agama Kalimantan Barat ini layak untuk dilakukan adalah sebagai berikut. Setelah penulis melakukan survei di dalam artikel laman kantor wilayah kementerian agama masih banyak ditemukan kesalahan penggunaan bahasa Indonesia dan tidak mengikuti aturan Pedoman Umum Ejaan Bahasa Indonesia (PUEBI) baik dalam bentuk ejaan, maupun kalimatnya. Setelah penulis menemukan masalah tersebut, penulis menjadi tertarik untuk melakukan sebuah penelitian tentang kebahasaan yang digunakan di dalam artikel laman kantor wilayah kementerian agama yang ada di Kalimanta Barat ini dengan tujuan untuk mendeskripsikan penggunaan bahasa pada artikel dalam laman kantor wilayah kementerian agama Kalimantan barat dan sebagai bahan pembelajaran bersama kedepannya agar tidak terjadi kesalahan yang sama dalam melakukan sebuah penulisan. Beberapa penelitian yang relevan sudah melaksanakan penelitiannya dengan hasil yang baik dan merekomendasikan untuk melanjutkan penelitian tersebut. Penelitian yang relevan adalah penelitian yang pernah dilakukan oleh sekelompok atau orang tertentu pada suatu bidang tertentu yang berkaitan atau memiliki tema yang sama dengan penelitian yang akan dilakukan oleh peneliti selanjutnya. Beberapa peneliti lain telah melakukan beberapa penelitian mengenai penggunaan bahasa yang mengkaji tentang ejaan, kalimat, dan diksi.

Penggunaan bahasa Indonesia pada artikel dapat diimplementasikan pada pembelajaran bahasa Indonesia di sekolah, yaitu membaca dan menulis. Pada Kurikulum 2013 mata pelajaran bahasa Indonesia di kelas XII terdapat Kompetensi Dasar yaitu 4.10 Menyusun opini dalam bentuk artikel dengan kegiatan pembelajaran menulis opini dalam bentuk artikel dengan memerhatikan unsur-unsur artikel. 


\section{METODE}

Metode penelitian yang penulis gunakan dalam penelitian ini adalah metode deskriptif. Metode deskriptif dapat diartikan sebagai cara yang akan dilakukan untuk memecahkan suatu masalah dengan cara memberikan gambaran objek dalam penelitian. Menurut Sugiyono, (2014: 16) data yang terkumpul berbentuk kata-kata atau gambaran, sehingga tidak menekankan pada angka. Metode deskriptif dilakukan dengan cara menggambarkan tentang apa yang dianalisis. Penelitian dengan metode deskriptif ini penulis berusaha memberikan gambaran tentang apa yang terjadi, dan menerangkan hasil analisis yang didapatkan melalui tulisan sehingga mendapatkan suatu makna dari sebuah permasalahan yang terdapat dalam penelitian ini.

Bentuk penelitian yang digunakan penulis dalam penelitian ini adalah penelitian kualitatif. Bentuk penelitian kualitatif yaitu suatu bentuk menemukan, menguraikan, dan menjelaskan. Menurut Strauss dalam Ahmadi (2016: 15) menyatakan bahwa "penelitian kualitatif adalah suatu jenis penelitan yang menghasilkan temuan-temuan yang tidak diperoleh oleh alat-alat prosedur statistik atau alat-alat kuantifikasi lainnya".

Penelitian yang dilakukan yaitu sebuah penelitan tentang kesalahan penggunaan ejaan, kalimat, dan diksi. Penulis akan menganalisis subjek penelitian dengan menghubungkan antara teori dengan faktafakta yang ada. Peneliti juga akan berusaha menggambarkan dan menginterprestasikan permasalahan dengan apa adanya. Menurut Strauss dalam Ahmadi, (2016: 12) Alasan penulis melakukan penelitian kualitatif adalah keyakinan penulis berdasarkan pengalaman penelitian yang pernah dilakukan.

Sumber data merupakan tempat dimana penulis akan mendapatkan data sebagai bahan penelitiannya nanti. Menurut Muhsin (2013: 28) hal yang ada kaitannya dengan data adalah menyangkut sumberdata yang di dalamnya terdapat masalah-masalah yang berhubungan dengan populasi, sampel, dan informan. Sumber data yang digunakan dalam penelitian ini adalah laman Kantor Wilayah Kementerian Agama Kalimantan Barat dengan situs http:// kalbar.kemenag.go.id/id.

Data merupakan sekumpulan fakta yang akan disusun menjadi suatu informasi. Data dalam penelitian ini adalah ejaan, kalimat, dan diksi yang ada di dalam artikel. Artikel yang dianalisis dalam penelitian ini dari periode Oktober 2017- Januari 2018 dengan jumlah sebanyak 26 artikel.

Teknik yang digunakan untuk mengumpulkan data dalam penelitian ini adalah studi dokumentasi dan teknik catat. Studi dokumentasi atau yang biasa disebut dengan kajian dokumentasi adalah suatu penelusuran data historis objek penelitian serta melihat sejauh mana proses yang berjalan dan apakah sudah berjalan dengan baik. Teknik pengumpulan data yang penulis lakukan yaitu dengan mengkaji dokumen-dokumen artikel yang ada dalam laman Kantor wilayah kementerian agama dengan tujuan untuk mendapatkan data-data yang diperlukan dan mencatatnya ke dalam kartu pencatat data.

Berdasarkan dari penjelasan sebelumnya, penelitian ini menggunakan alat pengumpul data dengan cara membaca terlebih dahulu kemudian menandai bagian yang tidak tepat, mencatat bagian yang salah dan mengelompokannya berdasarkan jenis kesalahannya menggunakan kartu pencatat data, baik itu berupa kesalahan ejaan maupun kesalahan pada kalimat.

Teknik yang penulis lakukan untuk menganalisis data dalam penelitian ini adalah analisis teks dengan cara mencocokan antara teori dengan pemakaian bahasa yang digunakan dalam artikel yang akan diteliti. Analisis teks tersebut digunakan untuk mendeskripsikan penggunan bahasa Indonesia dalam artikel yang akan diteliti. Langkah-langkah yang dilakukan penulis dalam menganalisis data adalah sebagai berikut.

1. Membaca artikel secara keseluruhan yang berjumlah 26 artikel.

2. Menandai bagian-bagian tulisan yang mengandung ejaan dan kalimat yang ada dalam artikel. 
3. Menulis dan mengelompokan bagian-bagian tulisan yang mengandung ejaan dan kalimat yang tidak tepat pada artikel di dalam kartu pancatat data.

4. Mendiskusikan dengan dosen pembimbing agar hasil analisis dapat teruji secara objektif.

5. Memperbaiki bagian-bagian penggunaan ejaan dan kalimat yang tidak tepat.

6. Melaporkan hasil analisis terhadap penggunaan bahasa Indonesia dalam artikel tersebut.

\section{HASIL DAN PEMBAHASAN}

Bagian ini berisi tentang hasil dari analisi permasalahan penggunaan bahasa yang terdapat pada artikel dalam laman kementerian agama Kalimantan Barat. Sebelum penulis melakukan analisi, hal yang terlebih dahulu dilakukan adalah membaca keseluruhan objek yang akan dianalisis. Setelah penulis membaca objek secara keseluruhan, penulis memberikan tanda pada bagian-bagian yang terdapat kesalahan sesuai dengan rumusan masalah yang ada. Kesalahan-kesalahan yang sudah diberi tanda tersebut kemudian dikelompokan sesuai dengan permasalahannya dalam kartu pencatat data.

Hasil penelitian yang akan disajikan oleh penulis berupa analisis kesalahan berbahasa yang mencangkup tentang ejaan, kalimat dan diksi. Berdasarkan dari hasil penelitian yang dilakukan tentang penggunaan bahasa Indonesia pada artikel yang terdapat dalam laman Kementerian Agama Kalimantan Barat, penulis menemukan sebanyak 439 data kesalahan dalam penggunaan bahasa yaitu: a. penggunaan ejaan sebanyak 161 data; b. penggunaan kalimat sebanyak 145 data; c. penggunaan diksi sebanyak 133 data. Sesuai dengan hasil penelitian dan masalah penelitian. Penulis menyajikan hasil analisis dalam bentuk tabel untuk hasil yang lebih detailnya.

Tabel 1 Hasil Analisis Kesalahan Penggunaan Bahasa

\begin{tabular}{|c|c|c|c|c|}
\hline \multirow[t]{2}{*}{ No. } & \multirow[t]{2}{*}{ Judul Artikel } & \multicolumn{3}{|c|}{ Jumlah Data } \\
\hline & & Ejaan & Kalimat & Diksi \\
\hline 1. & Manusia Melenial & 7 & 5 & 7 \\
\hline 2. & Manusia Konflik & 7 & 4 & 5 \\
\hline 3. & Manusia Jagung & 8 & 5 & 5 \\
\hline 4. & Manusia Abu-abu & 7 & 2 & 5 \\
\hline 5. & Buku Teman Sejati Bagi Guru & 7 & 8 & 6 \\
\hline 6. & Profesi Guru Sangat Mulisa & 6 & 8 & 3 \\
\hline 7. & MembangunGuru Berintegritas Anti Korupsi & 6 & 7 & 5 \\
\hline 8. & Madrasah Sebagai Lembah Pendidikan Alternatif & 12 & 8 & 4 \\
\hline 9. & Jadi Guru yang Diidolakan & 12 & 4 & 4 \\
\hline 10. & Kesadaran Guru Sebagai Tonggak Pendidikan Karakter & 3 & 4 & 5 \\
\hline 11. & Pendidikan Indonesia: Kehilangan Arah? & 2 & 6 & 7 \\
\hline 12. & Indonesia, We Love You & 7 & 6 & 3 \\
\hline 13. & Istriku, Terima Kasih Seibu \% & 3 & 5 & 5 \\
\hline 14. & $\begin{array}{l}\text { Memaknai Hari Santri Sebagai Hari yang Bersejarah } \\
\text { Bagi Bangsa Indonesia }\end{array}$ & 7 & 4 & 4 \\
\hline 15. & Mazhab Medsos & 5 & 5 & 6 \\
\hline 16. & Berbahagialah Orang yang Sedikit & 7 & 5 & 3 \\
\hline 17. & Anak Kita, Anak Masa Depan & 2 & 4 & 10 \\
\hline 18. & $\begin{array}{l}\text { Tuhan, Maafkan Aku Telah Negative Thinking } \\
\text { Padamu }\end{array}$ & 7 & 5 & 6 \\
\hline & Mencari Cinta Sang Pemilik Cinta & 7 & 2 & 5 \\
\hline & From Zero To Hero & 6 & 5 & 5 \\
\hline & Belajar dari Umar bin Khathab & 4 & 8 & 5 \\
\hline & Manusia Wajib & 4 & 6 & 4 \\
\hline 23. & Pengembangan Madrasah Bertaraf Internasional & 9 & 4 & 3 \\
\hline 24. & Filosofi Iqra & 4 & 10 & 6 \\
\hline
\end{tabular}




\begin{tabular}{ccccc}
\hline 25. & Burung Kakaktua yang Su'ul Khatimah & 9 & 7 & 7 \\
\hline 26. & Ketika Hidup Berorientasi Dunia & 3 & 8 & 5 \\
\hline Jumlah Data & 161 & 145 & 133 \\
\hline
\end{tabular}

Penggunaan bahasa Indonesia pada artikel yang terdapat dalam laman Kementerian Agama Kalimantan Barat

a. Penggunaa Ejaan

Ejaan merupakan sebuah tatacara mengungkapkan ragam bahasa tulisan agar tidak terjadinya kesalah pahaman antara penulis dengan pembaca. Perwandari dan Qoni'ah (2015: 18) menyatakan bahwa "ejaan adalah suatu sistem aturan tentang cara menuliskan bahasa dengan menggunakan huruf, kata, dan tanda baca sebagai sarananya sehingga jauh lebih luas dari sekedar masalah pelafalan, karena mengatur keseluruhan cara menuliskan bahasa". Adapun bentuk kesalahan penggunaan ejaan pada artikel dalam laman Kementerian Agama Kalimantan Barar sebagai berikut.

Data 1

1) ...apa yang tidak mungkin sekarang ajdi kenyataan, (http://kalbar.kemenag.go.id/id/opini/manusia-milenial)

Penjelasan:

Terdapat kesalahan pada kata 'ajdi' seharusnya 'jadi'. Kesalahan tersebut tergolong dalam bentuk kesalahan penulisan kata.

2) ....apa yang musthail...

(http://kalbar.kemenag.go.id/id/opini/manusia-milenial)

Penjelasan:

Terdapat kesalahan pada kata 'musthail' seharusnya 'mustahil'. Kesalahan tersebut tergolong dalam bentuk kesalahan penulisan kata.

Data 2

3) Ditulis oleh sholihin

(http://kalbar.kemenag.go.id/id/opini/manusia-konflik)

Penjelasan:

Terdapat kesalahan pada kata 'sholihin' seharusnya diawali huruf kapital 'Sholihin' karena nama orang.

4) orang-orang disekitarnya merasa aman dari gangguan lisan dan tangannya.

(http://kalbar.kemenag.go.id/id/opini/manusia-konflik)

Penjelasan:

Terdapat kesalahan pada kata 'disekitarnya' seharusnya dipisah menjadi 'di sekitarnya'. Karena kata 'di' tersebut bukan imbuhan yang menunjukan bentuk dari kata kerja melainkan bentuk dari kata depan yang menunjukan tempat.

5) Hidup adalah pilihan, menjadi orang yang dikenal sebagai orang yang bermanfaat dan bijakkah atau diberikan label sebagai manusia ...

(http://kalbar.kemenag.go.id/id/opini/manusia-konflik)

Penjelasan:

Terdapat kesalahan peggunaan partikel pada kata 'bijakkah' seharusnya 'bijak' cukup dan partikel 'kah' dihilangkan. Karena saat ada partikel -kah di depan kata bijak seakan itu diikuti tanda tanya.

b. Penggunaan Kalimat 
Kalimat yang terdapat dalam ragam tulisan merupakan suatu bentuk susunan kata yang memiliki makna dan bisa dipahami oleh pembaca. Menurut Keraf dalam Perwandari dan Qoni'ah (2015: 65) "kalimat merupakan suatu bentuk bahasa yang mencoba menyusun dan menuangkan gagasangagasan seseorang secara terbuka untuk dikomunikasikan kepada orang lain". Adapun kesalahan penggunaan kalimat efektif pada artikel dalam laman Kementerian Agama Kalimantan Barar sebagai berikut:

Data 1

1) ....., dulu untuk menginformasi berita bisa hingga 6-7 hari perjalanan surat tertulis. (http://kalbar.kemenag.go.id/id/opini/manusia-milenial)

Penjelasan:

Kalimat tersebut terdapat kata yang tidak logis, yaitu pada kata menginformasikan berita. Kata berita mengandung makna kumpulan informasi, sedangkan kata yang mendahuluinya adalah kaya menginformasikan. Seharusnya kata tersebut diganti dengan kata menyampaikan. '....., dulu untuk menyampaikan berita bisa hingga 6-7 hari perjalanan surat tertulis.

Data 2

2) Dengan pola pikir seperti ini maka dapat dipastikan dimanapun ia berada akan membawa kehancuran, .....

(http://kalbar.kemenag.go.id/id/opini/manusia-konflik)

Penjelasan:

Terdapat kesalahan pemborosan kata dalam kalimat tersebut yaitu pada kata maka yang seharusnya dihilangkan saja. Seharusnya kalimat yang digunakan, 'Dengan pola pikir seperti ini dapat dipastikan dimanapun ia berada akan membawa kehancuran, .....'

Data 3

3) Bandingkan dengan manusia jambu monyet, pelajaran apa yang dapat pembaca ambil dan dijadikan sebagai pemaknaan kehidupan.

(http://kalbar.kemenag.go.id/id/opini/manusia-jagung)

Penjelasan:

Terdapat kesalahan ketidak sejajaran dalam kalimat tersebut yauitu kata ambil dan dijadikan. Seharusnya kata ambil juga mendapatkan imbuhan di- agar menjadi kalimat yang sejajar. Seharusnya kalimat tersebut adalah 'Bandingkan dengan manusia jambu monyet, pelajaran apa yang dapat diambil pembaca dan dijadikan sebagai pemaknaan kehidupan.'

Data 4

4) Hal ini disinggung oleh Allah SWT sebagaimana ditemukan dalam QS. AsySyams/91: 8 bahwa manusia diberikan potensi kebaikan dan potensi keburukan.

(http://kalbar.kemenag.go.id/id/opini/manusia-abu-abu)

Penjelasan:

Terdapat kata yang tidak logis dalam kaliat tersebut yaitu pada kata disinggung karena kata tersebut tidak efektif, agar lebih efektif menggunakan kata difirmakan. Kemudian kata ditemukan karena kata tersebut tidak efektif, agar lebih efektif menggunakan kata tercantum. 'Hal ini difirmankan oleh Allah SWT sebagaimana tercantum dalam QS. Asy-Syams/91: 8 bahwa manusia diberikan potensi kebaikan dan potensi keburukan.'

Data 5

5) ..... untuk mengembangkan dirinya kearah yang lebih baik dan berkualitas maka sudah dapat dipastikan suasana pembelajaran akan menjadi kaku. 
(http://kalbar.kemenag.go.id/id/opini/buku-teman-sejati-bagi-guru)

Penjelaan:Terdapat kesalah pemborosan kata pada kalimat tersebut yang terdapat pada kata sudah dapat. Seharusnya kata sudah dihilangan, seharusnya kalimat yang digunakan ialah '.... untuk mengembangkan dirinya kearah yang lebih baik dan berkualitas maka dapat dipastikan suasana pembelajaran akan menjadi kaku.'

\section{c. Penggunaan Diksi}

Diksi merupakan pemilihan kata dalam membuat sebuah tulisan yang bertujuan untuk menghindari kesalah pahaman antara penulis dengan pembaca. Seorang penulis harus memiliki sebuah teknik penyajian agar tulisannya lebih mudah dipahami oleh pembaca. "Teknik pengkajian yang dimaksud adalah bagaimana seorang penulis mampu memilih kata yang tepat, memiliki makna denotasi, tidak membuat ambiguitas makna, dan pola logis pembaca" (Pamungkas, 2012: 72). Banyak hal yang harus diperhatikan dalam pemilahan kata agar di dalam penulisan tidak terjadi makna yang sulit untuk dipahami pembaca. Pamungkas (2012: 99) ada empat persyaratan yang harus dipertimbangkan dalam pemilihan kata seperti berikut.

1. Ketepatan

Kata yang dipilih hendaknya dapat mewadahi konsep atau gagasan yang akan disampaikan secara tepat.

2. Kesesuaian

Kata yang dipilih sebaiknya dipertimbangkan kesesuaiannya dari segi lingkungan sosialbudaya pemakai dan lingkungan linguistiknya.

3. Kelaziman

Kelaziman berkaitan dengan masalah keterkaitan kata dalam pemakaian bahasa.

4. Kebenaran

Kebenaran berkaitan dengan masalah ketaatan pemakaian kaidah bahasa.

Adapun kesalahan penggunaan diksi pada artikel dalam laman Kementerian Agama

Kalimantan Barar sebagai berikut:

Data 5

1) Guru sebagai pendidik harus selalu 'mengupdate' ilmunya.

(http://kalbar.kemenag.go.id/id/opini/buku-teman-sejati-bagi-guru)

Penjelasan:

Terdapat kesalahan dalam pemilihan kata yang tidak tepat pada penulisan dalam kalimat tersebut. Seharusnya kalimat yang tepat ialah 'Guru sebagai pendidik harus selalu memperbarui ilmunya'.

2) Bagaimana mungkin guru akan bisa menjamu serta memberikan 'servis' yang terbaik kepada anak didiknya,

(http://kalbar.kemenag.go.id/id/opini/buku-teman-sejati-bagi-guru)

Penjelasan:

Terdapat pemilihan kata yang tidak tepat dalam kalimat tersebut yaitu kata 'servis'. Perbaikan yang tepat ialah 'Bagaimana mungkin guru bisa mengajar serta memberikan materi yang terbaik kepada anak didiknya'.

Data 6

3) Dan telah 'menggelutinya' dengan penuh dedikasi serta tangungjawab yang tinggi, ... (http://kalbar.kemenag.go.id/id/opini/profesi-guru-sangat-mulia)

Penjelasan:

Terdapat penggunaan kata yang tidak sesuai dalam kalimat tersebut yaitu pada kata 'menggelutinya'. Seharusnya 'Dan telah menjalaninya dengan penuh dedikasi serta tangungjawab yang tinggi, ...'

Data 7

4) Padahal, se $\neg$ kolah diharapkan menjadi 'lokomotif' dalam penguatan budaya antikorupsi.

(http://kalbar.kemenag.go.id/id/opini/membangun-guru-berintegritas-anti-korupsi) 
Penjelasan:

Ketetapan pemilhan kata yang kurang tepat dapat membuat pemaknaan ganda dalam sebuah kalimat. Seperti kata 'lokomotif', seharusnya kalimat yang digunkan ialah 'Padahal, se $\neg$ kolah diharapkan menjadi dasar dalam penguatan budaya antikorupsi'.

Data 8

5) Dengan demikian akumulasi pengalaman madrasah dalam proses pendidikan terukur dari usia madrasah yang telah tua.

(http://kalbar.kemenag.go.id/id/opini/madrasah-sebagai-lembaga-pendidikan-

alternatif)

Penjelasan:

Terdapat pemilihan kata yang tidak sesuai dalam kalimat tersebut. Seharusnya kalimat yang digunakan adalah 'Dengan demikian akumulasi pengalaman madrasah dalam proses pendidikan terukur dari lamanya madrasah itu dibangun'.

\section{KESIMPULAN DAN SARAN}

Berdasarkan dari rumusan masalah dan tujuan dari penelitian yang telah disampaikan pada bagian pembahasan yang sudah dijelaskan pada bab-bab sebelumnya dapat diambil kesimpulan sebagai berikut.

1. Penggunaan ejaan yang terdapat pada artikel dalam laman kementerian agama Kalimatan Barat sebanyak 161 kesalahan. Kesalahan tersebut berdasarkan hasil dari penelitian 26 artikel.

2. Penggunaan kalimat yang terdapat pada artikel dalam laman kementerian agama Kalimatan Barat sebanyak 145 kesalahan. Kesalahan tersebut berdasarkan hasil dari penelitian 26 artikel.

3. Penggunaan ejaan yang terdapat pada artikel dalam laman kementerian agama Kalimatan Barat sebanyak 133 kesalahan. Kesalahan tersebut berdasarkan hasil dari penelitian 26 artikel.

4. Implementasi pembelajaran pertama ditinjau dari kurikulum. Kurikulum yang digunakan adalah Kurikulum 2013 (K13). Menggunakan Kurikulum 2013 ini karena di sekolah yang bertaraf internasional sekarang sudah menggunakan Kurikulum 2013. Kurikulum 2013 merupakan kurikulum yang mengutamakan keaktifan siswa. Kedua ditinjau dari segi tujuan pembelajaran bahasa. Tujuan yang digunakan penulis untuk memberikan arahan terhadap rumusan kompetensi dasar yang lebih dikhususkan. Ketiga, dilihat dari segi pemilihan bahan ajar yang harus disesuaikan dengan kurikulum dan kompetensi dasar. Keempat, dilihat dari segi keterbacaan agar dapat dibaca dan lebih dipahami oleh peserta didik. Kelima, dilihat dari metode pembelajaran bahwa penulis menggunakan metode inquiry. Keenam, dilihat dari segi media pembelajaran penulis menggunakan media OHP (Overhead Projector). Ketujuh, dilihat dari segi evaluasi, keberhasilan peserta didik dalam pembelajaran dapat diukur dari penilaian berbentuk test yang disesuaikan dengan materi yang telah disampaikan.

\section{DAFTAR PUSTAKA}

Ahmadi, Rulam. 2016. Metodologi Penelitian Kualitatif. Yogyakarta: Ar-Ruzz Media.

Gunawan, dkk. 2012. Menulis Artikel Untuk Jurnal Ilmiah. Jakarta Selatan: Uhamka Press.

Pamungkas, Sri. 2012. Bahasa Indonesia dalam Berbagai Perspektif. Yogyakarta: CV Andi.

Purwandari dan Qoni'ah. 2015. Buku Pintar Bahasa Indonesia. Yogyakarta: Istana Media.

Sugiyono. 2014. Metode Penelitian Kombinasi (Mixed Methods). Bandung: Alfabeta, cv.

Suparlan. 2014. Panduan Lengkap Ejaan Yang Disempurnakan. Yogyakarta. Pustaka Baru Press 
Hasanah, Tika Qurratun. 2016. Penggunaan Bahasa Indonesia Pada Majalah Teknokra Edisi Tahun 2013-2015 dan Implikasinya. Fakultas Keguruan dan Ilmu Pendidikan Universitas Lampung. http://repository.lppm.unila.ac.id/ 4644/1/10813. Diakses pada (28/01/2018).

Suryani, Neneng. 2012. Penggunaan Bahasa Indonesia dalam Surat Keluar di Kantor Kecamatan Pengkadan Kapuas Hulu Tahun 2011/2012. FKIP Universitas Tanjungpura Pontianak. http://jurnal.untan.ac.id/index.php/ jpdpb/articel/view/3236. Diakses pada (28/01/2018).

Zubeir, Ahmad. 2008. Strategi Menulis Artikel di Koran Kadaulatan Rakyat. Universitas Islam Negara Sunan Kalijaga Yogyakarta. http://digilib.uin-suka.ac.id/1703. Diakses pada (28/01/2018). 